\title{
UKRAINIAN BORDER GUARDS INTEROPERABILITY ASSESSMENT IN THE FRAMEWORK OF COMMON EUROPEAN BORDER GUARD STANDARDS IMPLEMENTATION
}

\author{
Andrii Balendr \\ National Academy of the State Border Guard Service of Ukraine, Khmelnytskyi, Ukraine \\ drbalen@i.ua
}

Oksana Komarnytska

National Academy of the State Border Guard Service of Ukraine, Khmelnytskyi, Ukraine

o.i.komarnytska@gmail.com

Ihor Bloshchynskyi

National Academy of the State Border Guard Service of Ukraine, Khmelnytskyi, Ukraine

i.blochsh@ukr.net

\begin{abstract}
The paper reports on an innovative approach to evaluate the level of harmonisation of Ukrainian border guards training with the common standards for border guarding in the European Union (EU) member-states. There are different types of borders and different organisational structures in border guard agencies in the EU. The authors present the results of a research aimed at analysing the level of interoperability of Ukrainian border guards. In case of border guards' training, interoperability stands for their level of professional readiness for joint actions with representatives of foreign border guard authorities. For this purpose, the EU border guard agencies under the supervision of the European Border and Coast Guard Agency (Frontex Agency) introduced the Interoperability Assessment Program (IAP), as the means to assess, first of all, the level of integration of the Common Core Curriculum (CCC) for basic border guards' training into border guard authorities' national curricula. The programme's results provide information on the degree to which the CCC meets the requirements regarding its content. The overall CCC implementation at the NASBGSU was $77.5 \%$, namely: by modules (General Studies - 95\%; Land Border Module - 75\%; Air Border Module - 81\%; Sea Border Module - 58,6\%); by content (General studies - 96\%; Legislation - 73,9\%; Practice $-80,8 \%$ ). The results of the evaluation held at the National Academy of the State Border Guard Service of Ukraine named after Bohdan Khmelnytskyi, involving cadets of the Faculty of Foreign Languages and Humanities showed that Ukrainian border guards and their system of education and training are in line with the EU member-states' common standards and the Ukrainian border guard agency personnel can be effectively used for the various operational and service activities of protecting different border sectors.
\end{abstract}

Keywords: border guards' training; harmonisation; interoperability; common standards; European Union member-states; cooperation.

\section{Introduction}

The State Border Guard Service of Ukraine (SBGSU) actively participates in the international cooperation projects, in particular, in the field of border guards training with different counterparts across the globe. Participation of Ukrainian border guards in such initiatives, especially with the European Union (EU) countries provides the opportunity to develop and improve the national border guard authority using the best state-of-the-art tools and practices of European law enforcement agencies; get acquainted with the latest technologies in the field of the state border protection; utilise modern personnel training methods in order to improve professional training of Ukrainian border guards and enhance the image of the SBGSU among law enforcement agencies in the European and world arena.

Speaking about the countries of EU, there are different needs and priorities when it comes to border protection because there are different types of borders and different organisational structures when it comes to the management of border guard agencies. For example, Ukraine has all types of borders, while Austria and Hungary have no sea borders, or Malta and Iceland have no land borders. With 28 member-states, the EU countries have a diverse range of approaches to border guarding. There is a need for harmonisation in this sphere, especially in terms of training. That's why the EU countries came up with an idea not to replace the national system of training, but to create a training framework which allows border guards from different countries to work effectively together. It becomes invaluable during joint missions at the border when representatives of different agencies can use the same methods, standards and terminology (Annual Activity Report, 2016).

Frontex Agency (European Border and Coast Guard Agency) is an organisation which provides border control of the EU external borders. The Agency actively promotes the development of European integrated

Balendr, A., Komarnytska, O., \& Bloshchynskyi, I. (2019). Ukrainian border guards interoperability assessment in the framework of common European border guard standards implementation. Advanced Education, 12, 35-43. DOI: 10.20535/2410-8286.128196 
border management (IBM), which involves the use of best practices in education and training of border guards, ranging from basic operating level to tactical and strategic management, development of a common border guard culture and common practices in the EU in order to ensure efficient cooperation of the sphere of personnel training. Therefore, the SBGSU Administration decided to participate in joint educational projects of the EU Member States in order to continue adaptation of the system of Ukrainian border guards' training according to European and world standards.

Nowadays, Frontex continues developing and implementing common standards that could be shared among all the EU countries in order to achieve interoperability. The term "interoperability" means the ability of diverse systems and organisations to work together. Speaking about law enforcement bodies activities, interoperability aims to co-operability among people. Operability is the ability to keep a system in a functioning and operating condition. Interoperability is a property referring to the ability of diverse systems and organisations to work together (interoperate). Interoperability is a term that encompasses more than simply whether parts can work together and certainly extends to the notion of the proper overall functioning of all elements of inter-operating systems (Miller, 2010). "Interoperability" begins with mutual understanding, shared know-how and friendly personal relations (Paile-Calvo, 2016).

In case of border guards' training, "interoperability" stands for their level of professional readiness for joint actions with representatives of foreign border guard authorities. The principles of IBM require that border guard activities should be compatible across borders. Whenever common operations are needed at the external borders, the participating officers should have a common understanding which can only be reached via harmonised basic training (Common Core Curriculum, 2017).

Nowadays, the SBGSU faces the challenge of reforming its system of border guards training according to the modern European requirements in the sphere of education and training of personnel. One of the options for solving this problem is the active use of the experience of other EU border guard agencies and Frontex Agency, such as developing national curricula on the basis of the best practice of EU border guard agencies, modernisation of the SBGSU distance learning system; organisation of the educational process in the departmental educational institutions of the SBGSU in accordance with the Sectoral Qualifications Framework (SQF) for border guarding in order to modernise the content of the departmental educational and professional standards; considering the possibilities for mobile learning; the possibility of accreditation of training courses at the educational institutions of the SBGSU; participation of SBGSU educational institutions in the network of Frontex Partnership Academies (Balendr, 2018).

With the purpose to harmonise the border guards' training in all EU and Schengen Associated Countries, Frontex Agency initiated development and implementation on the national level of a Common Core Curriculum (CCC) for border guard basic training. The CCC is consistent with the aims and priorities of the Copenhagen process and focuses on the development of an integrated approach to education and training policies at European level. The CCC offers benefits to the EU Member States by reflecting common training standards. It has been translated into different languages and its implementation is proceeding at different stages in different Member States. Frontex Agency aims to European-wide joint operations with EU Member States (MS). The ability of border guards from different countries to perform their service duties together can only be found out and verified by carrying out a common evaluation. Thus, Frontex Agency has launched a 3-year Interoperability Assessment Program (IAP). This project aims to produce a measurement system with the help of scientific research and contribution by experts from different MS. By means of IAP, the purpose is to obtain objective and accurate information concerning the extent to which the common standards have been reached. This programme will benefit the whole EU and also its individual MS and their respective training Academies (Interoperability Assessment Program Study, 2015).

The research of the theory and practice of border guards' professional training has been conducted by Bloshchynsky (2017) and others. However, our studies have shown that there is hardly any current thorough analysis of the problem of utilising common standards for border guarding in the EU countries in the system of Ukrainian border guards' training. Therefore, the purpose of the article is to determine the level of interoperability of Ukrainian border guards in terms of implementation of common educational standards of the border guards of EU countries.

\section{Methods}

The research included 2 stages - implementation of the CCC into the training system of the SBGSU and knowledge evaluation of the cadets who have completed their training by CCC. Following the introduction of the CCC into national curricula, the training process was directed in such a way that the students receive the same knowledge, skills and competencies that would be required for the fulfilment of professional border guard duties, regardless of the country of study. The solution of this problem is an integral part of systemic 
reforms in Ukraine in order to integrate into the European law-enforcement community, in particular, in the context of establishing a European model for the border protection authorities in Ukraine.

As for defining the target population, its size, properties and limits - in case of Ukrainian Border Guard students, the population involved the 4th year cadets, future border guard officers of the National Academy of the SBGSU named after Bohdan Khmelnytskyi (NASBGSU), the Faculty of Foreign Languages and Humanities. The number of cadets who took part in the all-European assessment project was defined as 15.

The apparatus used included computer based online multiple-choice evaluation on the basis of Virtual Aula web-platform using two measurement types: the judgement-based assessment study and the multiplechoice items study. In the first case, the study was based on open-ended questions and the judges had to be selected and trained to assess responses on a similar basis in each country. In the second case, which is largely used in PISA (Program for International Student Assessment), the designing of items is more difficult and time-consuming and items have to be pre-tested to guarantee and find an acceptable group of test items. In the case of multiple-choice items, the analyses are made with special programmes. Classical Item Analysis (CIA) is needed to analyse the multiple-choice alternatives in each question (item). To analyse the items in the whole test and to produce person scores, the item response theory (IRT) programmes are needed. The simple multiple-choice items do not need judges to assess, but the analyses are carried out with IRT programmes. The student score will be one result of item analyses. Multiple-choice item consists of a stimulus (a picture, text-passage, etc.), question and response alternatives. All alternatives should be equally plausible as far as possible. Each border guard agency had to organise the test in their country, but the results were collected to the common international coordination centre, where the data was checked, cleaned and accepted for the final analyses (Nikkanen, 2009).

In order to utilise time, as well as human and material resources effectively and to reach the envisaged goals, a job-knowledge evaluation concept was selected. Being aware of the fact that there are limitations to knowledge evaluations, the assessment has been devised in such a way as to also determine the acquisition of the necessary skills, attitudes and behaviours for job performance. The main idea was to create "a pool" with 120 questions/items. All 120 questions were openly available for students and teachers before the test. 65 questions were randomly selected for the pilot test from the pool. Some of the items were multiple-choice items. Images and video episodes were also used. The border guard experts from all participating countries produced more such items and sought consensus on them in IAP working group meetings. The following chapters of categories of CCC were included by the experts of the working group:

General Studies: Development of border control, Politics and policies of the EU and other European organisations, Applied psychology, Communication skills and public relations, Professional ethics, Human rights, English language training;

Law enforcement studies: EU community law and international legislation; Crime investigation; Document examination; Organised crime;

Practical skills: Information technology; Tactical procedures for BG activities; Technical equipment; First Aid and occupational health Hazards; Overview on air, land and sea borders; Cooperation and coordination with other authorities.

\section{Results}

The international project results SBGSU took part in, have shown the level of harmonisation with the border guards' training standards existing in the countries of the EU. The study was carried out in the light of the inconsistency of views and approaches on the state border protection between the personnel of the SBGSU and representatives of the border guard authorities of the EU countries.

Therefore, according to the plan of cooperation with the Frontex Agency, first of all, the national working group was appointed by the Administration of the SBGSU, including the authors of the article, who also were chosen as the national experts on CCC implementation in the SBGSU. The group members agreed upon the plan with the respective representatives of the Personnel Management of the SBGSU Administration.

According to the plan, the comparison of the national curricula and CCC was conducted in order to determine the compliance of the national programmes with the EU border guarding requirements. The heads of educational departments of the NASBGSU were involved in fulfilling this task. After a profound analysis of the CCC content, the heads of the 24 educational departments of the National Academy excluded the provisions of the CCC the use of which was limited due to the requirements of the current Ukrainian legislation. The next step was defining the provisions that were viewed as mandatory according to the requirements of the Ministry of Education of Ukraine, as well as normative-legal documents of the SBGSU. The mission set for the working 
group was a new one in a methodological sense, so the authors conducted a series of train-the-trainer courses on the CCC usage with the representatives of the departmental educational institutions.

After outlining the course of actions in general, the working group of the National Academy came to the point of writing job competencies and learning outcomes clear for the EU border protection community in order to develop professionally-oriented courses for both Ukrainian and EU countries' border guards. With this purpose in mind the authors took part in "Course design training according to the SQF for border guarding" held at the Police Academy in Innsbruck, Austria, in 2017; in Romania in 2016; Slovak Republic 2014, 2016.

The next stage was the development of the national curricula in accordance with national educational standards, SQF and CCC. After that, the working group, in close collaboration with the heads of the educational departments, initiated the implementation of certain CCC modules into the future training courses. An experimental border guards' basic training course based on the CCC was developed at the SBGSU Personnel Training Center in Orshanets, Cherkassy region, and later, having analysed the national peculiarities, it was successfully implemented in the educational process of that educational establishment. At the NASBGSU, after substantial discussions, the heads of the departments agreed to harmonise the contents of the curricula of the respective departments with the topics defined in the CCC.

In 2017 the working group of the NASBGSU, according to the request of the Frontex Training Unit performed the CCC Implementation Status evaluation. The National Academy was asked to provide the actual status of the CCC implementation, which was 77.5\%. Implementation by modules was: General Part 95\%; Land Border Module - 75\%; Air Border Module - 81\%; Sea Border Module - 58,6\%. Implementation by the content type: Generic studies $-96 \%$; Legislation $-73,9 \%$; Practice $-80,8 \%$ (Figures 1,2).
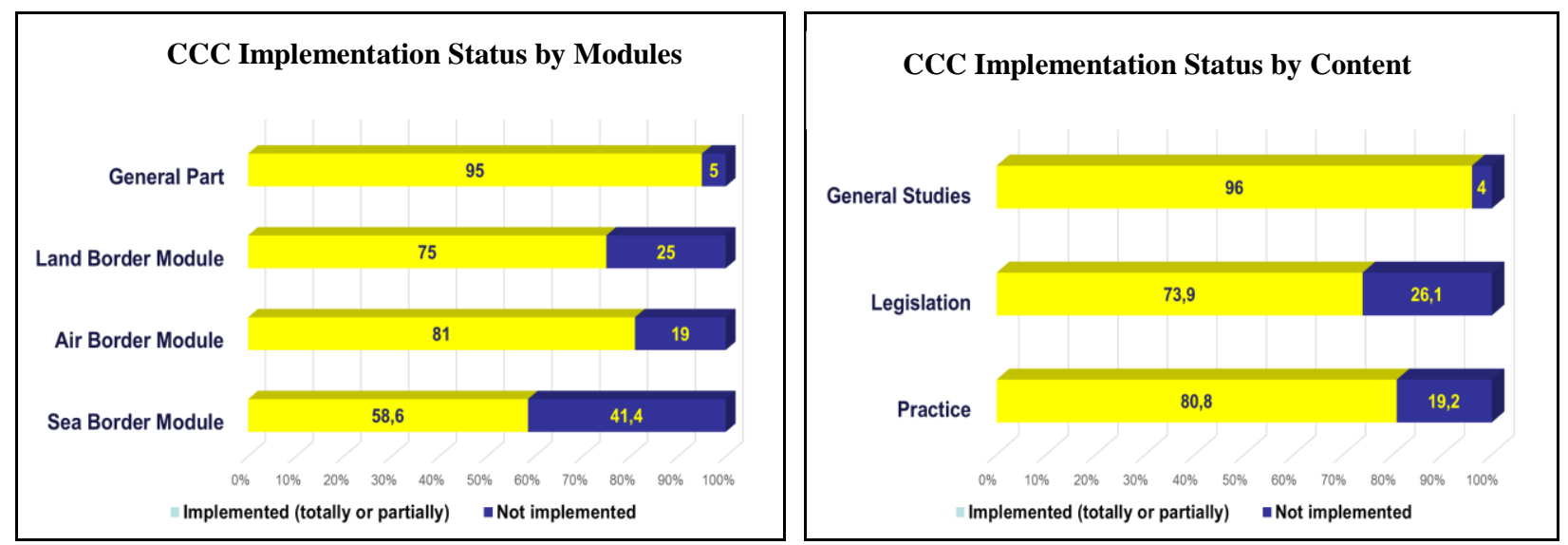

Figure 1, 2. CCC Implementation Status in the SBGSU by Modules and Content

Altogether, the picture of CCC implementation into the system of Ukrainian border guards' training is the following (Table 1):

Table 1. Overall CCC Implementation Status in the SBGSU

\begin{tabular}{|l|l|l|l|}
\hline Module/Chapter & $\begin{array}{l}\text { Implemented } \\
\text { completely, \% }\end{array}$ & $\begin{array}{l}\text { Implemented } \\
\text { in part, \% }\end{array}$ & $\begin{array}{l}\text { Not implemented, } \\
\%\end{array}$ \\
\hline GENERAL STUDIES - 95\% (aver., completely and in part) \\
\hline Generic studies & 53 & 43 & 4 \\
\hline Law enforcement Studies & 59 & 36 & 5 \\
\hline Practical Skills & 57 & 77 & 6 \\
\hline AIR BORDER MODULE - 81\% (aver., completely and in part) \\
\hline Specific legislation & 11 & 67 & 22 \\
\hline Specific practice & 21 & 63 \\
\hline LAND BORDER MODULE - 75.1\% (aver., completely and in part) \\
\hline Specific legislation & 50 & 12.5 & 37.5 \\
\hline Specific practice & 54.4 & 12.3 \\
\hline SEA BORDER MODULE $-\mathbf{5 8 . 6 \%}$ (aver., completely and in part) \\
\hline Specific legislation & - & 60 & 40 \\
\hline Specific practice & 28.6 & 28.6 & 42.8 \\
\hline
\end{tabular}


Having completed the CCC implementation part of the project, the knowledge assessment of the cadets who have completed their training by this curriculum was conducted in all the countries of EU and Schengen Associated Countries. The members of the Ukrainian working group participated in the elaboration of the materials for the all-European IAP. Under the supervision of the Frontex project managers, they took part in the development of the multiple-choice tests for assessing the possibility of cooperation and interaction between border guards who have undergone training according to the CCC.

From April 2014 till March 2015, 865 border guards from 18 EU member states, Schengen Associated Countries and Working Arrangement Countries conducted an evaluation in 34 sessions. The students were in their final stages of their border guard studies, in 2014 - 2015, having been trained on the basis of CCC. Countries provided the data related to the implementation of CCC in their national curricula and organised and hosted the evaluation sessions of their border guard students. The evaluation session was organised and observed in every participating academy by at least one invigilator, who was present and ensured the compliance of procedures and activities. An online multiple-choice evaluation containing 70 items from the CCC chapters relevant to interoperability was chosen as the form of evaluation (Interoperability Assessment Program Study, 2015).

In December 2017, in the framework of the IAP project, the next stage of the programme was held at the NASBGSU. The testing of border guard cadets was conducted online, using remote computer access to the test programme stored on the Frontex Agency server, with the automatic receiving of the test results (system requirements: the computer class with approximately 20 workplaces equipped with a high-speed Internet connection, installed browser and flash player). The test was carried out under the supervision of three experts from the EU countries. The cadets had to be pre-registered for the test on the web-platform Virtual Aula, open an account and receive access to the test programme. Participation in the test involved the personnel of the Faculty of Foreign Languages and Humanities consisting of 15 cadets of the $4^{\text {th }}$ year of study. The participants successfully passed the test. The results of the Ukrainian future border guard officers' level of knowledge according to CCC was $87 \%$ and that testified to their level of interoperability with European counterparts and proved their ability to take part in various Frontex initiatives on guarding border sectors in joint teams of Ukrainian and EU border guards (Figure 3).

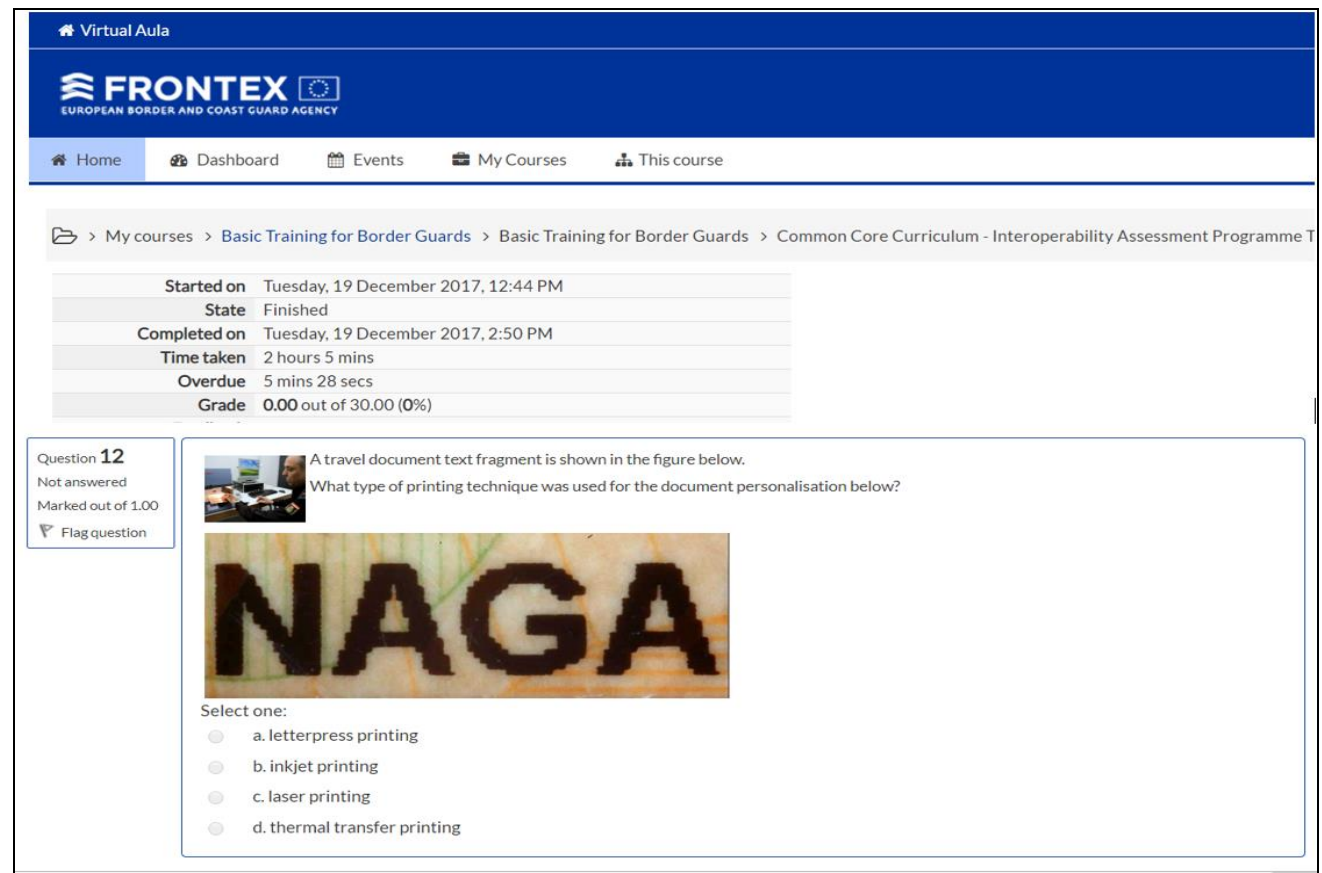

Figure 3. The online multiple-choice test sample

The learning results of the cadets' knowledge evaluation have been regarded in three parts: General Studies $-76 \%$, Law enforcement Studies $-77 \%$ and Practical Skills $-77 \%$.

So, regarding the General Studies module, the majority of students gave correct answers to the questions about: 1. BGv (Border guard values) - 99\% of the answers were correct; 2. Ac (Anti-corruption) - 97\% of the answers were correct; 3 . Pch (Protection of children) $-99 \%$ of the answers were correct; 4 . Cd (Cultural diversity) $-99 \%$ of the answers were correct; 5. Pi (Principles of interviewing) - 91\% of the answers were correct. The smallest number of correct answers was given to the questions about: 1. Aps (Applied psychology) $-36 \%$ of the answers were correct; 2 . Fcc (Frontex Code of Conduct) $-43 \%$ of the answers 
were correct; 3. EUpp (EU Politics and Policies) - 49\% of the answers were correct; 4. Cc (Cultures of customers) $-53 \%$ of the answers were correct; 5 . Ccm (Communication and conflict management) $-56 \%$ of the answers were correct (Figure 4).

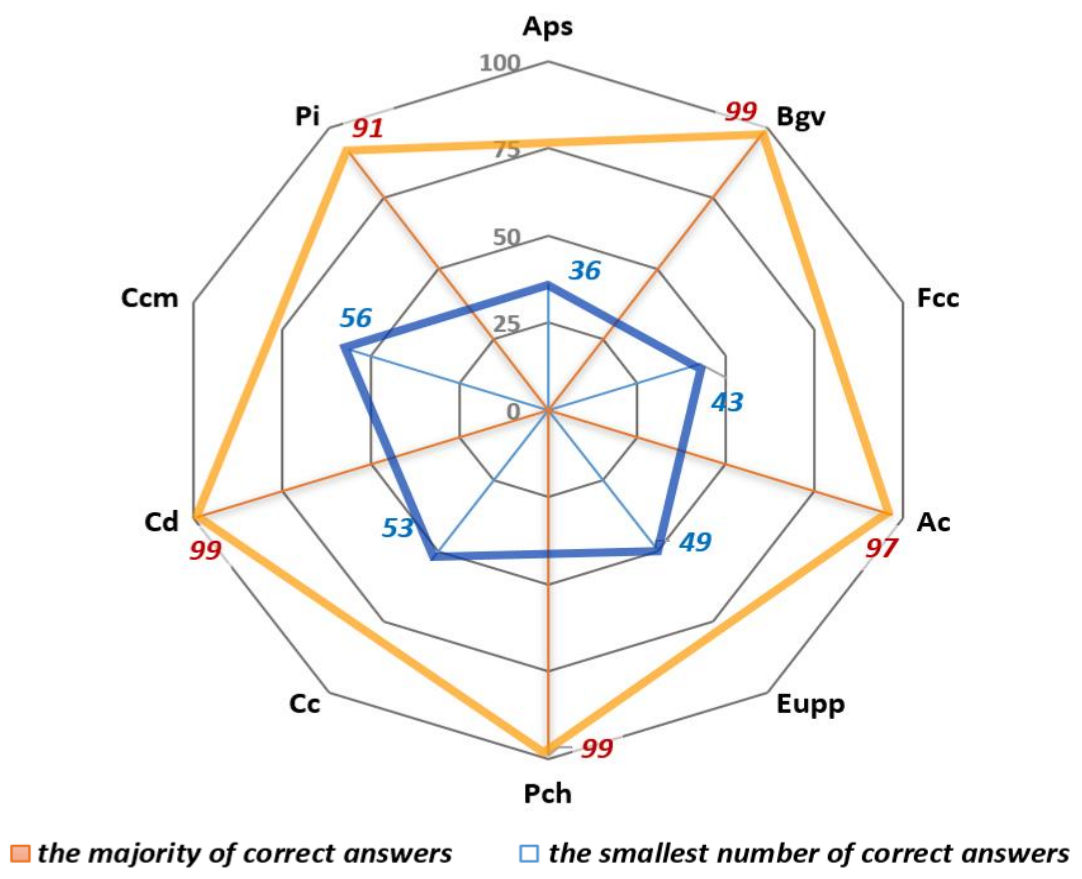

Figure 4. General Studies Module Implementation

Speaking about Law Enforcement Studies Module Implementation, the majority of students gave correct answers to the questions about: 1 . Be (Basic equipment) $-97 \%$ of the answers were correct; 2 . VcEUr (Visa Code and other EU regulations) - 89\% of the answers were correct; 3. Sbc-sch (The Schengen Border Code) $-88 \%$ of the answers were correct. The smallest number of correct answers was given to the questions about: 1. EUibm (EU Integrated Border Management) - 39\% of the answers were correct; 2. Sbctcn (The Schengen Border Code, third country nationals check) $-68 \%$ of the answers were correct; 3 . Da (Document analysis) $-53 \%$ of the answers were correct (Figure 5).

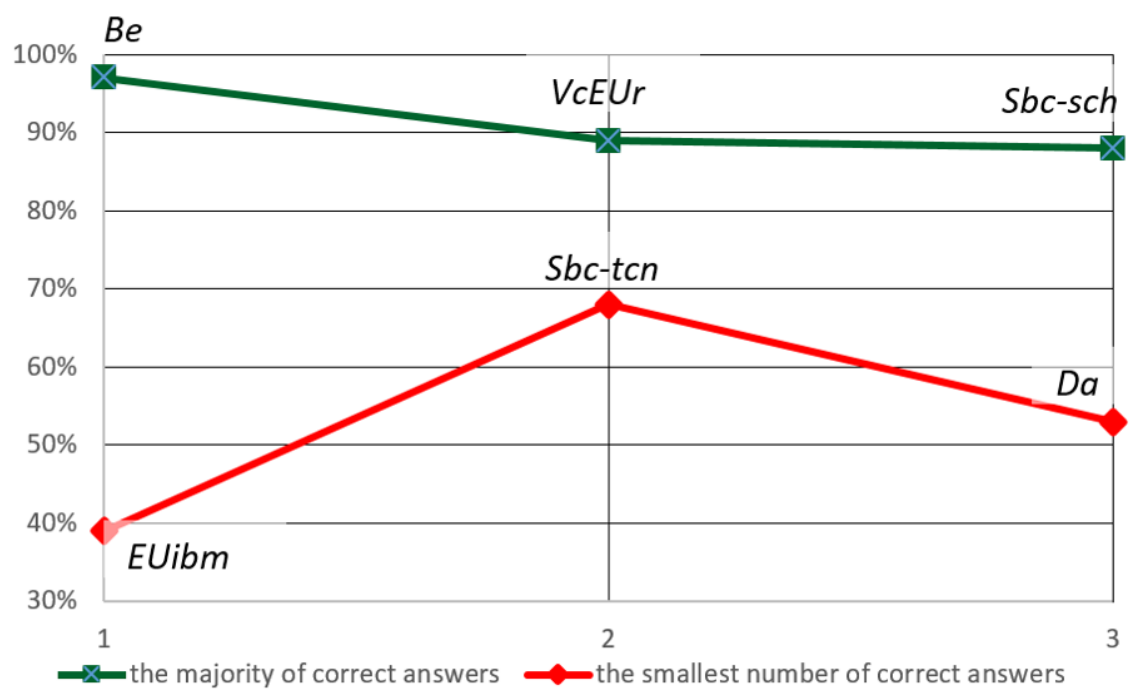

Figure 5. Law enforcement Studies Module Implementation

According to the results of the Practical Skills Module implementation, the majority of students gave correct answers to the questions about: 1 . Hh (Health hazard) $-98 \%$ of the answers were correct.

The smallest number of correct answers was given to the questions about: 2. Sb (Sea Borders) - 56\% of the answers were correct (Figure 6). 


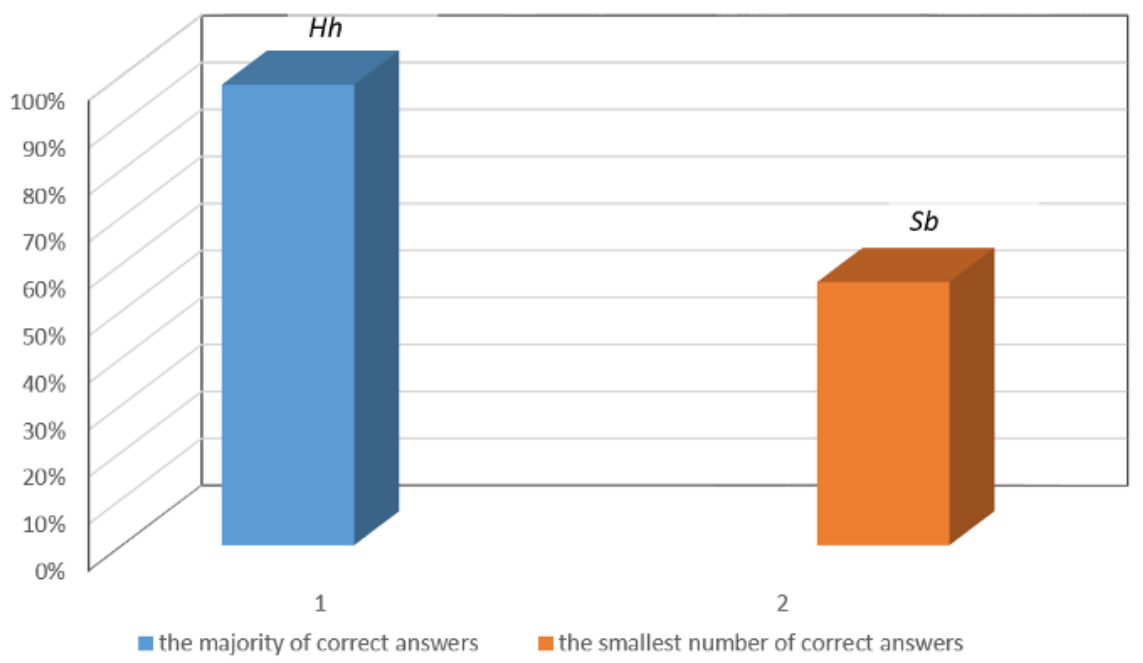

Figure 6. Practical Skills Module Implementation

According to the results of the training needs analysis in the sphere of the border guard agencies personnel training, the SBGSU is quite actively taking part in the EU border guard training initiatives. The overall CCC implementation at the NASBGSU is 77.5\%, namely: by modules (General Studies - 95\%; Land Border Module - 75\%; Air Border Module - 81\%; Sea Border Module - 58,6\%); by content (General studies - 96\%; Legislation - 73,9\%; Practice $-80,8 \%$ ). The study allowed to verify and confirm the professional knowledge level of Ukrainian border guards, which is regarded by the European border guard community high enough for the personnel of the SBGSU to take part in joint Border guard operations together with other Border Guard agencies of EU countries.

\section{Discussion}

Nowadays, despite the existence of a common legal framework, border checks and surveillance practices often vary among the EU countries. Therefore, the EU border control capacities need to be unified, including the harmonisation of technical equipment and working practices in order to make the border control more efficient and effective. The EU border guard community focuses on the following objectives in the sphere of personnel training: learning standards elaboration; common culture and harmonised competences development; quality standards, best practice, EU guidelines sharing; validation and recognition of training; trainers' certification, accredited training for mid and high-level managers (Training Needs Assessment Report, 2016).

Participation in the Frontex projects allows Ukrainian border guards to take part in international projects and programmes, namely: detection of stolen cars, forged documents, dog-handlers' training, professional English language training, also using the web platform Virtual Aula for cooperation and training in the border protection sphere with European counterparts; exchanging information and performing joint risk analysis, expanding the risk analysis network in the Eastern Partnership countries; training of personnel skilled in law enforcement activities according to the European and international standards; optimising the structure of the national law enforcement authorities and reforming their management system.

Empirical analysis has shown that a set of procedures and mechanisms developed by Frontex has increased the participation of the state border agencies in EU's border guard activities, which implies the shift of the intergovernmental interaction to a more structured form of cooperation. It has also found that, although the outcome has been unevenly spread in Europe, Frontex has acted as an agent of transfer in promoting common standards for border guard training curricula and automated border control systems (Horii, 2015).

Some of the Agency's main activities and products in this area include best practices and guidelines; capability tools; studies and study visits; working groups; workshops; meetings. The information gathered through these activities about current practices, challenges and needs are disseminated to all relevant internal and external stakeholders, such as Member States, European Commission, EU agencies, international organisations and standardisation bodies as well as non-EU countries (Frontex Annual Activity Report, 2016).

The organisational structure of Frontex Agency comprises, among others, the Training unit, which provides coordination and standardisation of training of about 400,000 border guards in the EU countries. The major result of the Agency is the development of the CCC for border guards of the EU countries. The 
CCC was developed under the guidance of Frontex, with the support of over 40 experts from 21 countries, faculty at universities and international organisations. The CCC is designed as the general border guard academy course; it is divided into a generic studies section for all categories of the border guard personnel, and specific sections for land, sea and air border guards (Common Core Curriculum, 2017).

Frontex has also developed a mid-level CCC equivalent to a Bachelor degree, it serves as a measurement and assessment tool with assistance from university-based experts. Frontex also organises special short-term courses on topics of interest and relevance. Topics for which special courses have been developed so far include vehicle inspection groups training, aircrew training, dog handling, quick response units, joint returns, and English language, human rights, air-border-related law, asylum seekers, use of force and Schengen evaluation training, the fundamental rights and law courses (Marenin, 2010).

The SBGS of Ukraine started a close cooperation with the EU border guard authorities in the sphere of the personnel education and training in 2011, with the Frontex Agency's project of CCC implementation. The first seminar on CCC translation and implementation was organised in 2012 in Iasi, Romania, where the authors as the Ukrainian border guard authority representatives took part. Form 2012 till 2015 the SBGSU was studying and step by step introducing CCC in the departmental educational institutions.

Following the introduction of the CCC into national curricula, the training process was directed in such a way that students could obtain the same knowledge, skills and relevant attitudes that were required for fulfilment of professional border guard duties, regardless of the country of study. The solution of this problem became an integral part of systemic reforms in Ukraine in order to integrate into the European law enforcement community, in particular, in the context of establishing a European model for the border protection authorities in Ukraine. Therefore, in 2016 within the framework of cooperation of the SBGSU and Frontex Agency, the authors participated in the project regarding CCC updating and its alignment with the $\mathrm{SQF}$ for border guarding. The work was held in the form of plenary meetings and working groups at the Agency headquarters. Participants attended lectures on the introduction of new approaches to border guards training, studied B. Bloom's taxonomy, acquired necessary skills to develop learning outcomes using defined verbs of the given taxonomy, determined the problem issues of CCC that required updating. CCC was developed in line with the principles of the Bologna and Copenhagen processes and is focused on a competence-based approach to European border guards training. In such a way, the initiatives of Frontex Agency contribute a lot to the capacity building of European and Ukrainian border guard authorities. The elaboration of educational tools, such as CCC allows to establish common grounds for border guards of different countries and make national curricula more flexible for accomplishing operational and service tasks at the borders.

\section{Conclusions}

Nowadays, the Ukrainian border guards are facing a challenge of combating global threats at the border, and that makes the border guard agencies of EU countries and also Ukraine search for new and effective ways of the personnel training. The SBGSU actively takes part in the Frontex Agency's projects in the sphere of the border guard agencies personnel training. Ukrainian border guard agency has implemented and integrated CCC into its national curricula at the NASBGSU and the SBGSU Training Center. The results of implementation show that teaching process based on the common European standards is manifested by the sense of unity with other European border guard organisations and helps effectively solve common problems of global nature. The SBGS of Ukraine has cooperated with the EU border guard agencies in the sphere of the personnel training since 2011. The representatives of Ukrainian border guard authority have taken an active part in developing and implementing common European border guard standards since that time. It can, therefore, be stated that common standards are widely implemented, used and highly appreciated in Ukraine. The leadership of the SBGSU is supporting Frontex initiatives as the first step to implement harmonised European standards.

In order to ensure as a complete implementation of CCC as possible and evaluate the level of interoperability of EU border guards, the Frontex Agency initiated the IAP. Ukrainian border guard agency took an active part both at the stage of the online test elaboration and later during the organisation of testing in Ukrainian border guard educational institutions. The overall quality of results of the IAP testing of the group of 15 cadets of the Faculty of Foreign Languages and Humanities at the National Academy of the SBGSU was $87 \%$ of correct answers, which showed that Ukrainian border guards and their system of education and training are in line with the EU countries common standards. The SBGSU personnel interoperability level is adequate for effective participation in the various operational and service activities of protecting different border sectors together with the border guards of EU countries. 


\section{References:}

Balendr, A. (2018). Stvorennya dystantsiynoho kursu navchannya prykordonnykiv za haluzevoyu ramkoyu kvalifikatsiy na osnovi platformy Virtual Aula [Designing professionally oriented training courses for border guards in accordance with the sectoral qualifications framework based on the virtual aula platform]. Information Technologies and Learning Tools, 63 (1), 68-80. Retrieved May 26, 2018 from https://journal.iitta.gov.ua/index.php/itlt/article/view/1807/1293

Bloshchynsky, I. (2017). Enhancement of cadets' practical training at the National Academy of the State Border Guard Service of Ukraine named after Bohdan Khmelnytskyi. Science and Education, 4, 5-10. https://doi.org/10.24195/2414-4665-2017-4-1

Frontex Annual Activity Report (2016). Warsaw, Poland: European Agency for the Management of Operational Cooperation at the External Borders of the Member States of the European Union. Retrieved February 26, 2018 from http://www.statewatch.org/news/2017/aug/eu-Frontex-activity-report-2016.pdf

Frontex Training Portfolio (2017). Warsaw, Poland: European Agency for the Management of Operational Cooperation at the External Borders of the Member States of the European Union. Retrieved February 26, 2018 from https://Frontex.europa.eu/publications/?category=training

Horii, S. (2015). Frontex and the Evolution of Cooperation on European Border Controls. Doctoral thesis (PhD), University of Sussex. Retrieved 15 July, 2018 from http://sro.sussex.ac.uk/id/eprint/58522/1/Horii,\%20Satoko.pdf

Interoperability Assessment Program Study (2015). Warsaw, Poland: European Agency for the Management of Operational Cooperation at the External Borders of the Member States of the European Union.

Marenin, O. (2010). Challenges for Integrated Border Management in the European Union. Occasional paper - №17. Geneva Centre for the Democratic Control of Armed Forces (DCAF). Retrieved March 12, 2018 from http://www.dcaf.ch/sites/default/files/publications/documents/OP17_Marenin.pdf

Miller, P. (2000). Interoperability: What Is It and Why Should I Want It? Ariadne, 24 Retrieved February 26,2018 from http://www.ariadne.ac.uk/issue24/interoperability

Nikkanen, P., Törmäkangas, K., Kupari, P., Malin, A., Välijärvi, J., Valkonen, S., \& Niilo-Rämä, M. (2009). CCC / IAP Common Core Curriculum Measurement System /Interoperability Assessment Programme. Final Report. Frontex Agency.

Paile-calvo, S. (2016). From European Mobility to Military Interoperability - Exchanging Young Officers, Knowledge and KnowHow. Luxembourg, Publications Office of the European Union.

Training Needs Assessment Report (2016). Warsaw, Poland: European Agency for the Management of Operational Cooperation at the External Borders of the Member States of the European Union. Retrieved March 16, 2018 from http://sro.sussex.ac.uk/ 